\title{
Analisis Faktor Eksploratori dan Konfirmatori untuk Validasi Skala Lingkungan Makan Terstruktur pada Ibu Bekerja
}

\author{
Rohmah Rifani $^{1}$, Suryanto ${ }^{2}$, Dewi Retno Suminar ${ }^{3}$ \\ ${ }^{1,2,3}$ Program Studi Psikologi, Universitas Airlangga, J1. Airlangga 4-6, Surabaya, Indonesia \\ ${ }^{1}$ Program Studi Psikologi, Universitas Negeri Makassar, Jl. A.P. Pettarani, Makassar, Indonesia \\ e-mail: rohmahrifani-13@psikologi.unair.ac.id
}

\begin{abstract}
This study aims to develop and validate the construct of structured meals environment scale. The method used was a cross-sectional survey. The participants were working mothers with earlyaged children. The structured meals environment scale used Likert scale which consists of three dimensions: structured meals setting, structured meals timing, and family meals setting. The results of EFA $(N=302)$ showed that the scale explains the construct of a structured meals environment was $63.98 \%$. The results of CFA $(N=202)$ showed that the goodness of fit model was acceptable. Factors loading > .5 (.503 - .819) shows the items are valid. Discriminant validity (AVE) moves from $.482-.577$ with construct reliability > .7 (.760 - .802). Structured meals environment scale has met the psychometric property test so that the scale is proper to be used.
\end{abstract}

Keywords: structured meals environment, validity, reliability

\begin{abstract}
Abstrak
Penelitian ini bertujuan untuk mengembangkan alat ukur dengan melakukan validasi konstrak pada skala lingkungan makan terstruktur. Metode yang digunakan yaitu survey cross-sectional. Karakteristik responden yaitu ibu bekerja, memiliki anak usia dini, dan berdomisili di Makassar. Skala lingkungan makan terstruktur menggunakan skala Likert yang terdiri dari tiga dimensi: structured meals setting, structured meals timing, dan family meals setting. Hasil Exploratory Factor Analysis (EFA) pada $\mathrm{N}=302$ menunjukkan skala mampu mengukur konstrak lingkungan makan terstruktur sebesar $63.98 \%$. Hasil confirmatory factors analysis (CFA) dengan $\mathrm{N}=202$ menunjukkan goodness of fit model dapat diterima. Factors loading > $.5 \quad(.503-.819)$ menunjukkan item mampu mengukur observed variable. Validitas diskriminan (AVE) bergerak dari .482 - .577 dengan construct reliability > .7 (.760 - .802). Skala lingkungan makan terstruktur telah memenuhi uji properti psikometrik sehingga dapat diaplikasikan.
\end{abstract}

Kata kunci: lingkungan makan terstruktur, validitas, reliabilitas

\section{Pendahuluan}

Masalah gizi anak masih menjadi problem di Indonesia. Kasus malnutrisi masih tergolong tinggi. Masalah obesitas maupun gizi buruk/ kurang masih menjadi skala prioritas dalam masalah kesehatan. Data kasus obesitas (11.5\%) dan masalah kekurangan gizi (19.9\%) masih tergolong tinggi. Kasus stunting masih berada pada angka 36.4\% (WHO-JME, 2017).

Obesitas berdampak pada kesehatan dalam jangka pendek maupun jangka panjang. Dampak jangka panjang seperti timbulnya penyakit kardiovaskuler, diabetes melitus tipe 2, kanker, anemia, penyakit saluran pencernaan, dan darah tinggi. Sedangkan dampak psikologis seperti marginalisasi dan stigmatisasi dalam pergaulan yang mengakibatkan depresi, rendahnya harga diri, dan kualitas hidup (Ogden, 2014). Kekurangan gizi dapat mengakibatkan anemia yang berdampak pada kesehatan dan perkembangan mental seperti prestasi belajar (Adriani \& Wirjatmadi, 2014).

Ibu merupakan penjaga gawang pada kasus obesitas. Obesitas pada masa anakanak dapat berlanjut pada masa remaja 
bahkan hingga dewasa (Ogden, 2014). Sedangkan kasus kekurangan gizi dapat mengakibatkan stunting. Kasus stunting masih tergolong tinggi akibat anak kurang mengkonsumsi cukup nutrisi. Kekurangan gizi tidak semata-mata diakibatkan oleh masalah ekonomi saja namun dapat disebabkan karena adanya problem perilaku makan pada anak (Adriani \& Wirjatmadi, 2014).

Prevalensi problem perilaku anak masih tergolong tinggi (kurang lebih 30\% hingga $61 \%$ ) pada anak usia di bawah lima tahun (Casey dkk., 2011). Di Indonesia kasus problem perilaku anak juga masih tergolong tinggi yaitu mencapai $51 \%$ (Rifani dkk., 2015). Problem perilaku makan anak seperti anak usil atau tidak tenang pada saat makan, anak hanya makan makanan tertentu hingga menutup mulut dan tidak mau makan. Kasus yang paling banyak dialami para ibu yaitu anak memilih-milih makanan dan hanya makan makanan tertentu saja $(26.8 \%)$. Hal ini menjadi salah satu penyebab anak mengalami kekurangan gizi.

Adanya problem perilaku makan pada anak menjadi kendala tersendiri bagi ibu dalam memberi makan anak. Ibu bekerja menjalankan peran ganda yaitu bertanggung jawab terhadap pekerjaan dan mengasuh anak, khususnya memberi makan. Hal ini menyebabkan ibu mengalami kendala waktu (time constraint). Sebagai contoh ibu membutuhkan waktu yang lama dalam memberikan sarapan pagi, terutama pada anak yang mengalami problem perilaku makan. Di sisi lain, ibu harus memenuhi tuntutan untuk bekerja. Kendala waktu menjadi salah satu hambatan yang sering dihadapi dalam memberi makan anak (Morin dkk., 2013; Rifani dkk., 2015).

Ibu memiliki peran penting dalam parenting, khususnya dalam memberi makan anak yang sifatnya rutinitas seharihari. Ibu yang mengatur dan menentukan lingkungan makan anak. Yang dimaksud mengatur lingkungan makan yaitu bagaimana ibu menetapkan aturan dan menjalankan secara konsisten aturan tersebut. Hal ini menuntut penegakan disiplin dalam pembentukan pola perilaku makan sehat. Dalam parenting, menyediakan struktur (providing structure) dalam hal ini lingkungan makan terstruktur merupakan salah satu tugas dan tanggung jawab ibu dalam memenuhi tugas perkembangan anak (Holden, 2014).

Pembentukan pola perilaku makan sehat salah satunya dengan cara disiplin dalam mengatur jadwal makan, tempat makan (meals setting), dan makan bersama keluarga. Hal ini dapat dilakukan dengan cara menyusun jadwal 3 kali sehari secara teratur, variasi makanan, jumlah porsi, makan di meja makan, dan makan bersama keluarga.

Anak yang dikenalkan pola makan sehat secara rutin sesuai lingkungan makan terstruktur sejak usia dini, kecenderungan hal ini akan berlanjut hingga dewasa. Apabila orang tua gagal dalam menegakkan aturan makan, anak cenderung tidak mampu mengatur pola makannya. Hal ini dapat mengakibatkan kurang mampu meregulasi diri terkait perilaku makan. Anak yang kurang mampu mengontrol nafsu makan sehingga makan dengan porsi berlebih cenderung mengalami obesitas. Anak yang malas makan cenderung mengalami kekurangan gizi (Ogden, 2014).

Mengatur lingkungan agar terorganisir untuk memfasilitasi suatu kompetensi dalam parenting dikenal dengan istilah struktur lingkungan (Grolnick dkk., 2014). Konsep ini dikembangkan berdasarkan perspektif teori self-determination (Deci \& Ryan, 2012; Grolnick dkk., 2014). Struktur lingkungan yang baik akan memfasilitasi perasaan kompeten yang merupakan salah satu dimensi teori self-determinism. Teori ini diderivasi dari ecological system theory, teori yang menjelaskan pengaruh lingkungan terhadap perilaku (Holden, 2014).

Pada bahasan ini struktur lingkungan terkait dengan perilaku makan anak 
digunakan istilah lingkungan makan terstruktur (structured meals environment). Lingkungan makan terstruktur didefinisikan sebagai mengorganisir dan mengatur lingkungan makan (Daniel, 2019). Ibu yang mampu menetapkan aturan dan konsisten menjalankan aturan dengan disiplin akan memudahkan ibu dalam membentuk pola perilaku makan anak. Aturan menjadi lebih jelas dan terstandar. Hal ini akan membuat ibu merasa lebih kompeten dalam mengorganisir dan mengatur perilaku makan anak. Ibu harus memperhatikan faktor yang menjadi pemecah konsentrasi pada saat makan (distract factor). Sebagai contoh ibu menjauhkan anak dari lingkungan yang membuat anak tidak fokus makan (games, televisi, handphone, dan lain-lain).

Menyediakan struktur lingkungan makan dengan mempertimbangkan setting yaitu apakah perilaku tersebut sesuai, berbahaya, tidak sehat, atau bertentangan dengan nilai, dan tujuan ibu. Terdapat berbagai cara yang dapat dilakukan ibu dalam mengatur dan mengorganisir lingkungan makan anak (Holden, 2014). Pertimbangan dan alasan dalam menyediakan struktur berbeda-beda sehingga penyusunan alat ukur yang dikembangkan pun beragam sesuai dengan tujuan dilakukannya penelitian.

Jansen (2014) mengembangkan alat ukur lingkungan makan terstruktur yang terdiri atas 3 dimensi yaitu: structured meals setting, structured meals timing, dan family meals setting. Bahkan Snugg dkk. (2019) telah mengembangkan alat ukur dengan tujuan yang lebih spesifik yaitu mengukur family mealtime (The Family Mealtime Goals Questionnaire). Beberapa riset bahkan tidak menyebutkan alat ukur skala lingkungan makan terstruktur sebagai variabel tersendiri. Namun peneliti menggunakan konstrak dan istilah yang berbeda seperti frekuensi makan pada keluarga (family meal frequencies) yaitu makan pagi, siang, dan malam (Melbye dkk., 2013; Murashima dkk., 2011).
Selain tujuan atau alasan peneliti, faktor lain yang berpengaruh yaitu budaya. Budaya memiliki pengaruh terhadap aturan dan tata cara makan. Ibu cenderung mengikuti norma budaya setempat dalam mengatur dan mengorganisir lingkungan makan anak (Holden, 2014). Aturan dan tata cara makan memiliki persamaan dan perbedaan antara budaya yang satu dengan yang lain. Persamaan budaya seperti frekuensi makan tiga kali dalam sehari memiliki kesamaan antara orang Indonesia dengan negara lain yaitu makan pagi, makan siang dan makan makan. Namun dalam pelaksanaan secara individu berlaku norma subjektif pada setiap keluarga seperti keluarga tertentu hanya makan dua kali sehari yaitu makan siang dan malam. Penting untuk mempertimbangkan budaya setempat dalam melakukan riset terkait perilaku makan. Adanya perbedaan feeding guidelines dan budaya yang berbeda menyebabkan pendekatan yang dilakukan ibu berbeda pada tiap negara, karena memberi makan anak dipengaruhi oleh akar budaya dan tradisi (Daniel, 2019).

Riset mengenai lingkungan makan terstruktur yang berlatar belakang budaya Indonesia masih terbatas, khususnya di Makassar. Budaya makan di etnis BugisMakassar memiliki tata cara makan tersendiri. Sebagai contoh masyarakat Ammatoa (suku dalam masyarakat Bugis) menganggap bayi yang gemuk adalah bayi yang sehat. Anak menangis dipersepsi lapar sehingga harus diberi makan. Bahkan anak dapat diberi makan sampai 5 kali sehari. Hal yang melatarbelakangi budaya tersebut adalah bahwa anak yang gemuk merupakan lambang kemakmuran karena daerah tersebut merupakan lumbung padi (Ibnu dkk., 2013). Aturan makan yang lain yaitu makan bersama anggota keluarga. Makan bersama pada waktu makan pagi, siang dan malam, namun jika ada kesibukan bekerja minimal makan malam. Tradisi makan bersama dilakukan duduk bersila dan membentuk lingkaran kecil (Kompasiana, 2015). 
Sebagai masyarakat yang beragama mayoritas Islam, masyarakat juga menganut etika makan dan minum sesuai syariah. Aturan berdasar ajaran agama seperti berdoa sebelum makan, makan tidak boleh berdiri, berhenti makan sebelum kenyang. Adab dan etika tersebut pada saat ini sering terabaikan bahkan hampir tidak dilakukan (Sohrah, 2016). Aturan tersebut nampak pada budaya makan bersama dengan duduk bersila dan berdoa sebelum makan pada masyarakat Bugis Makassar. Adanya perbedaan budaya dan tata cara memberi makan penting bagi peneliti untuk mempertimbangkan konstrak yang akan diteliti sesuai dengan budaya setempat.

Penelitian yang telah dilakukan di Indonesia, khususnya di Makassar belum secara spesifik menggunakan istilah lingkungan makan terstruktur. Variabel yang digunakan dalam penelitian masih berupa aspek-aspek yang terpisah seperti jadwal makan, aturan pada saat makan, jenis-jenis makanan, dan lain-lain (Fiamanatillah dkk., 2019; Aidid dkk., 2017). Hal ini menjadi alasan penulis untuk mengembangkan alat ukur agar dapat digunakan oleh peneliti selanjutnya.

Penting untuk mengeksporasi konstrak dan menyusun alat ukur yang sesuai dengan budaya Makassar. Penelitian ini bertujuan mengembangkan alat ukur lingkungan makan terstruktur. Uji validasi konstrak pada penelitian ini akan dilakukan dalam dua tahap yaitu validasi struktur internal melalui analisis faktor eksploratori dan konfirmatori.

\section{Metode Penelitian}

Penelitian ini menggunakan metode survey cross-sectional. Karakteristik responden yaitu ibu bekerja, memiliki anak usia 2-5 tahun, anak tidak mengalami gangguan atau kelainan organ makan, berdomisili di Makassar. Pengambilan sampel dilakukan melalui teknik cluster random sampling. Pengambilan data dilakukan pada lima sekolah di tiga kecamatan yang mewakili. Metode pengambilan data menggunakan teknik self report, menggunakan skala Likert dengan empat opsi jawaban sangat sering, sering, jarang, dan tidak pernah.

Langkah pengembangan alat ukur dilakukan melalui dua tahap yaitu studi 1 dan studi 2. Studi 1 yaitu eksplorasi konstrak, menyusun blue-print dan try-out pertama. Validasi konstrak berdasar struktur internal dilakukan dengan analisis faktor eksploratori (EFA). Tahap EFA dilakukan karena data masih merupakan hasil eksplorasi. Pengembangan alat ukur berdasar eksplorasi maupun adaptasi alat ukur yang berbeda budaya menurut para ahli disarankan menguji EFA (Osborne dkk., 2014). Studi 2 yaitu melakukan rekonfirmasi validasi konstrak dengan try out kedua pada kelompok responden yang berbeda. Validasi konstrak struktur internal menggunakan analisis faktor konfirmatori (CFA). Hasil ini mengukur apakah model fit dan item dapat mengukur observed variable.

Pada studi 1, penelitian diawali dengan mengeksplorasi konstrak lingkungan makan terstruktur, menyusun instrumen dan memvalidasi instrumen pengukuran melalui validasi internal struktur dengan EFA. Eksplorasi konstrak lingkungan makan terstruktur dilakukan dengan metode interview. Responden sebanyak delapan orang. Guide interview menggunakan pertanyaan terbuka seperti: "Ceritakan bagaimana cara ibu mengatur perilaku anak di saat makan?"; "Ceritakan apa saja yang ibu lakukan pada saat memberi makan anak?". Data hasil interview dianalisis oleh tiga orang peer review dan divalidasi oleh dua orang expert review. Peer review adalah orang yang ahli dalam bidang psikologi perkembangan anak dan expert review pakar dalam bidang psikologi perkembangan anak, psikologi keluarga dan feeding practices. Hasil analisis dapat disimpulkan skala lingkungan makan terstruktur terdiri dari tiga dimensi yaitu structured meals setting, structured meals timing, dan family meals setting. Ketiga 
dimensi ini menunjukkan kesesuaian dengan konstrak lingkungan makan terstruktur Jansen dkk. (2014). Dimensi inilah yang dikembangkan dalam menyusun skala lingkungan makan terstruktur.

\section{Alur dan Prosedur Penelitian}

Dalam menyusun blue-print skala lingkungan makan terstruktur, item disusun berdasarkan indikator dari masing-masing dimensi yang terdiri atas lima item. Jumlah item sebanyak lima belas. Item yang sifatnya favorable berjumlah 9 item dan unfavorable sebanyak 6 item. Penjelasan secara rinci dapat dilihat pada tabel 1. Skala menggunakan metode Likert dengan empat opsi pilihan jawaban (sangat sering, sering, jarang dan tidak pernah).

Skala lingkungan makan terstruktur divalidasi oleh tujuh expert judgement. Ketujuh expert merupakan orang yang ahli dalam bidang psikologi perkembangan anak, psikologi keluarga dan feeding practices. Expert tersebut menilai apakah item memiliki kesesuaian konstrak dengan indikator masing-masing dimensi. Penilaian dilakukan dengan cara memilih opsi (sangat sesuai, sesuai, tidak sesuai).

Hasil analisis content validty index (CVI) dapat diukur berdasarkan item (ICVI) dan skala secara keseluruhan (SCVI). CVI sebesar .83 minimal enam atau lebih jumlah pakar dianggap memiliki validitas isi yang baik (Yusoff, 2019). Validasi dilakukan oleh tujuh expert judgement telah memenuhi kriteria S-CVI maupun I-CVI. Hasil analisis menunjukkan nilai S-CVI maupun I-CVI sebesar 1. Artinya skala dan seluruh item-itemnya relevan mengukur konstrak lingkungan maka terstruktur. Validity based on process dilakukan dengan meminta expert review untuk menelaah apakah item sudah mengukur konstrak. Selanjutnya diuji coba keterbacaan item terhadap 10 responden dan merevisi berdasarkan masukan.
Langkah berikutnya setelah merevisi item, melakukan uji coba di lapangan untuk menguji validitas struktur internal (validity based on internal structure). Data $(\mathrm{N}=302)$ akan dianalisis menggunakan exploratory factors analysis (EFA). Validasi konstrak ini menguji alat ukur yang baru disusun atau ditranslasi atau diadaptasi di suatu negara atau budaya yang berbeda. Landasan EFA menggunakan data driven dalam mengeksplorasi suatu konstrak (Osborne dkk., 2014). Tujuan EFA untuk menentukan konstrak laten pada rangkaian item dalam suatu variabel dan mendefinisikan konstrak suatu faktor atau dimensi (Hu \& Li, 2015).

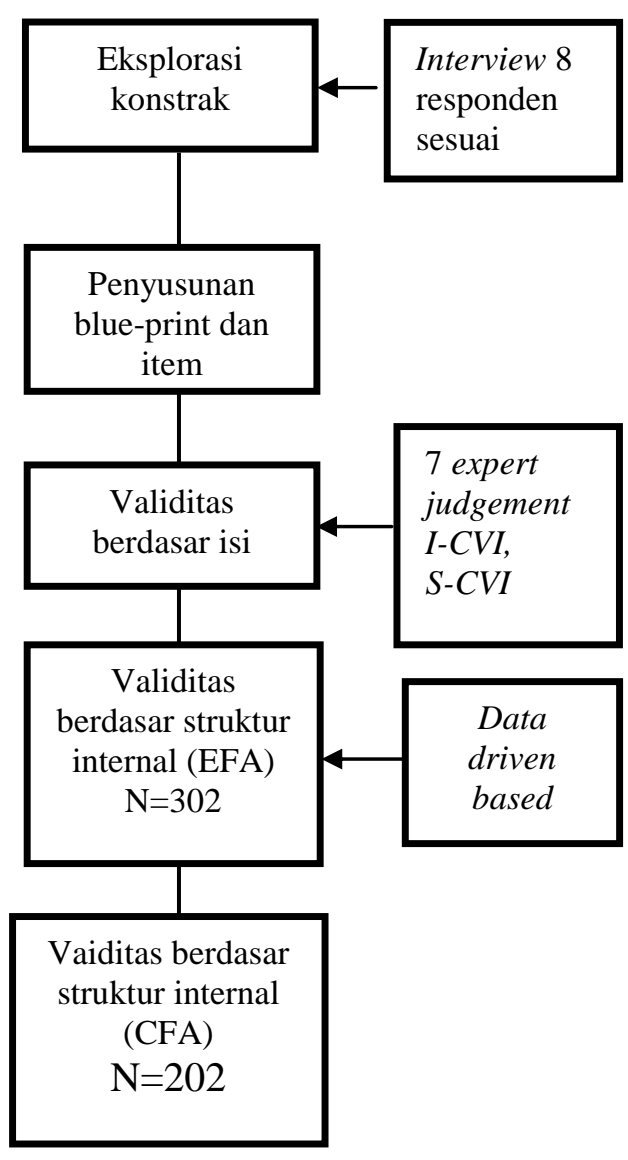

Gambarl. Bagan alur penelitian 
Tabel 1

Blueprint Skala Lingkungan Makan Terstruktur

\begin{tabular}{|c|c|c|}
\hline Dimensi & Indikator & Item \\
\hline \multirow[t]{5}{*}{$S M S$} & $\begin{array}{l}\text { Anak duduk } \\
\text { tenang dan sopan }\end{array}$ & $\begin{array}{l}\text { 1. Saya mengajarkan } \\
\text { anak supaya makan } \\
\text { dengan cara duduk } \\
\text { tenang dan sopan }\end{array}$ \\
\hline & $\begin{array}{l}\text { Memperhatikan } \\
\text { tata cara makan }\end{array}$ & $\begin{array}{l}\text { 2. Mengajarkan cara } \\
\text { makan yang benar } \\
\text { pada anak (duduk } \\
\text { yang baik) }\end{array}$ \\
\hline & $\begin{array}{l}\text { Makan di meja } \\
\text { makan }\end{array}$ & $\begin{array}{l}\text { 3. Saya menyuruh } \\
\text { anak makan di meja } \\
\text { makan }\end{array}$ \\
\hline & $\begin{array}{l}\text { Menemani saat } \\
\text { makan }\end{array}$ & $\begin{array}{l}\text { 4. Saya menemani } \\
\text { anak saat makan }\end{array}$ \\
\hline & & $\begin{array}{l}\text { 5. Saya memanggilkan } \\
\text { teman saat makan* }\end{array}$ \\
\hline \multirow[t]{5}{*}{$S M T$} & $\begin{array}{l}\text { Mengatur jadwal } \\
\text { makan }\end{array}$ & $\begin{array}{l}\text { 6. Saya memberi } \\
\text { makan anak } 3 \text { kali } \\
\text { sehari secara teratur }\end{array}$ \\
\hline & & $\begin{array}{l}\text { 7. Saya memberi } \\
\text { makan anak pada } \\
\text { saat lapar saja* }\end{array}$ \\
\hline & & $\begin{array}{l}\text { 8. Jadwal makan anak } \\
\text { saya tidak menentu* }\end{array}$ \\
\hline & & $\begin{array}{l}\text { 9. Saya mengatur } \\
\text { jadwal minum susu }\end{array}$ \\
\hline & $\begin{array}{l}\text { Mengatur jadwal } \\
\text { makan snack }\end{array}$ & $\begin{array}{l}\text { 10. Saya melarang anak } \\
\text { makan camilan di } \\
\text { saat mendekati } \\
\text { waktu makan utama }\end{array}$ \\
\hline \multirow[t]{5}{*}{$F M S$} & $\begin{array}{l}\text { Makan seperti } \\
\text { menu keluarga }\end{array}$ & $\begin{array}{l}\text { 11. Saya memasakkan } \\
\text { sendiri makanan } \\
\text { kesukaan anak* }\end{array}$ \\
\hline & & $\begin{array}{l}\text { 12. Anak makan } \\
\text { makanan yang sama } \\
\text { dengan menu } \\
\text { keluarga }\end{array}$ \\
\hline & & $\begin{array}{l}\text { 13. Anak mengikuti } \\
\text { aturan makan yang } \\
\text { berlaku di keluarga }\end{array}$ \\
\hline & $\begin{array}{l}\text { Waktu makan } \\
\text { yang sama } \\
\text { dengan keluarga }\end{array}$ & $\begin{array}{l}\text { 14. Anak makan sesuai } \\
\text { dengan waktu } \\
\text { makan keluarga }\end{array}$ \\
\hline & $\begin{array}{l}\text { Makan bersama } \\
\text { di meja makan }\end{array}$ & $\begin{array}{l}\text { 15. Anak makan } \\
\text { bersama di meja } \\
\text { makan bersama } \\
\text { keluarga }\end{array}$ \\
\hline \multicolumn{3}{|c|}{$\begin{array}{l}\text { SMS: Structured meals setting } \\
\text { SMT: Structured meals timing } \\
\text { FMS: Family meals setting }\end{array}$} \\
\hline
\end{tabular}

Peneliti memutuskan memilih metode ekstraksi Principal Axis Factoring (PAF) karena metode ini lebih sensitif untuk data yang kurang memenuhi asumsi normalitas (Osborne dkk., 2014). Metode rotasi yang digunakan promax (kappa 4) karena skala lingkungan makan terstruktur tergolong konstrak second order/ higher order. Interpretasi hasil analisis dapat dilihat pada nilai Kaiser-Meyer-Olkin (KMO) measure of sampling dan Barlett test sphericity. KMO bervariasi mulai $0-1$. Nilai 0 menunjukkan bahwa jumlah korelasi parsial relatif besar terhadap jumlah korelasi, menunjukkan difusi dalam pola korelasi (karenanya, analisis faktor tidak sesuai). Nilai mendekati 1 menunjukkan korelasi pola relatif kompak sehingga analisis faktor seharusnya menghasilkan faktor yang berbeda dan dapat diandalkan (reliable). Batas nilai yang dapat diterima adalah > .5. Nilai KMO $.5-.7$ (mediocre), $.7-.8$ (good), .8 - .9 (great), > .9 (superb). Nilai eigenvalues > 1 dapat dikatakan bermakna untuk menjelaskan faktor (Osborne dkk., 2014). Selain nilai eigenvalues, factor loading dapat digunakan untuk menentukan validitas konvergen (pattern matrix dan structure matrix untuk second order). Nilai factor loading lebih dari .4 dapat digunakan untuk menjelaskan komponen yang membentuk faktor (Osborne dkk., 2014). Data dianalisis dengan bantuan statistik melalui program komputer SPSS versi 24.

Pada studi 2, dilakukan rekonfirmasi validitas dan reliabilitas skala lingkungan makan terstruktur. Responden dengan kriteria yang sama sebanyak 202 orang telah mengisi skala lingkungan makan terstruktur. Uji coba kedua ini dimaksudkan untuk memverifikasi struktur faktor/ dimensi dari serangkaian observed variable (item). CFA menguji item dengan konstrak laten.

Uji model skala lingkungan makan terstruktur dilakukan untuk membuktikan apakah model fit serta item (observed variable) valid dan reliabel mengukur konstrak laten. Pedoman goodness of fit yaitu chi square dengan taraf signifikansi > .05 menunjukkan good fit, comparative fit index (CFI=>.90, good fit), goodness of fit index (GFI=.90, good fit), root mean square residual (RMSEA $\leq .080$, good fit), Normed fit index (NFI=.90, good fit) dan 
Analisis Faktor Eksploratori dan Konfirmatori untuk Validasi Skala Lingkungan Makan Terstruktur pada Ibu Bekerja (Rohmah Rifani, Suryanto, Dewi Retno Suminar)

Adjusted goodness of fit index (AGFI=.90, moderate fit). Batas kriteria untuk factor loading yang dapat diterima .5. Data dianalisis menggunakan bantuan statistik confirmatory factors analysis (CFA) melalui program komputer SEM Amos versi 24.

\section{Hasil Penelitian dan Pembahasan}

Data faktor demografik responden hanya ditampilkan dari data studi 1 . Data menunjukkan sebagian besar responden memiliki tingkat pendidikan diploma (52.6\%), dan pendapatan (income) tergolong pada kelas menengah (48.7\%). Lebih jauh dapat dikatakan bahwa sebagian besar responden telah menempuh pendidikan di perguruan tinggi (diploma, sarjana, magister/ doktor) yaitu sebanyak $69.1 \%$. dengan rerata pendapatan berada pada level kelas menengah, maka hanya $10.9 \%$ yang berada pada keluarga prasejahtera. Responden sebagian besar bekerja fulltime dengan waktu kerja tidak fleksibel. Responden bekerja dengan aturan yang cukup ketat dan disiplin sehingga mengalami keterbatasan waktu dalam memberi makan anak. Gambaran data faktor demografik responden dapat dilihat pada tabel 2 .

Hasil analisis exploratory factors analysis menunjukkan KMO sebesar .803 dan Barlett test sebesar 970.276, $\mathrm{p}=.000$ (signifikan). Artinya sampel cukup mewakili populasi. Nilai eigenvalues ketiga dimensi > 1 menunjukkan total varianced explained sebesar $63.987 \%$. Skala mampu menjelaskan konstrak lingkungan makan terstruktur sebesar $63.987 \%$, selebihnya dijelaskan oleh faktor lain. Sumbangan dimensi family meal setting (component 1) yaitu $38.349 \%$, dimensi structured meal setting (component 2) sebesar $13.97 \%$ dan structured meals timing (component 3) sebesar $11.662 \%$. Data dapat dilihat pada tabel 3. Tabel ini hanya menampilkan hasil analisis dengan nilai total eigenvalues $>1$.
Tabel 2

Data Status Sosial Ekonomi Responden

\begin{tabular}{lcc}
\hline \multicolumn{1}{c}{ Aspek } & $\Sigma \mathrm{N}$ & Persentase \\
\hline Tingkat pendidikan & & \\
$\quad$ SMP & 13 & 4.3 \\
SMA & 80 & 26.5 \\
Diploma & 159 & 52.6 \\
$\quad$ Sarjana & 46 & 15.2 \\
$\quad$ Magister/doktor & 4 & 1.3 \\
Income per bulan (Rp) & & \\
$\quad$ < 1 juta & 33 & 10.9 \\
1-5 juta & 147 & 48.7 \\
5-10 juta & 100 & 33.1 \\
>10 juta & 22 & 7.3 \\
Waktu kerja & & \\
$\quad$ Fulltime & 220 & 72.8 \\
Part time & 82 & 27.2 \\
Fleksibilitas waktu kerja & & \\
$\quad$ Fleksibel & 80 & 26.5 \\
Tidak fleksibel & 222 & 73.5 \\
Total (N) & 302 & 100 \\
\hline
\end{tabular}

Tabel 3

Total Variance Explained

\begin{tabular}{|c|c|c|c|}
\hline \multirow[b]{2}{*}{ Component } & \multicolumn{3}{|c|}{ Initial Eigenvalues } \\
\hline & Total & $\%$ of Variance & Cumulative $\%$ \\
\hline 1 & 3.835 & 38.349 & 38.349 \\
\hline 2 & 1.398 & 13.976 & 52.326 \\
\hline 3 & 1.166 & 11.662 & 63.987 \\
\hline
\end{tabular}

Tabel 4

Pattern Matrix dan Structure Matrix

\begin{tabular}{|c|c|c|c|c|c|c|}
\hline \multirow[b]{2}{*}{ Item } & \multicolumn{3}{|c|}{ Pattern matrix } & \multicolumn{3}{|c|}{ Structure matrix } \\
\hline & 1 & 2 & 3 & 1 & 2 & 3 \\
\hline SMS1 & & .896 & & & .883 & \\
\hline SMS2 & & .817 & & .409 & .857 & \\
\hline SMS3 & & .577 & & .481 & .689 & \\
\hline SMS4 & & & & & & \\
\hline SMS5 & & & & & & \\
\hline SMT1 & & & .755 & & & .765 \\
\hline SMT2 & & & .681 & & & .706 \\
\hline SMT3 & & & .747 & & & .732 \\
\hline SMT4 & & & & & & \\
\hline SMT5 & & & & & & \\
\hline FMS1 & & & & & & \\
\hline FMS2 & 689 & & & .649 & & \\
\hline FMS3 & .812 & & & .819 & & \\
\hline FMS4 & 697 & & & .772 & .411 & \\
\hline FMS5 & .878 & & & .880 & & \\
\hline
\end{tabular}

Ket: $\mathrm{SMS}=$ structured meals setting

SMT=structured meals timing

FMS=family meal setting 
Sebaran pengelompokan item berdasar hasil analisis factor loading dapat dilihat pada pattern matrix dan structure matrix pada tabel 4. Berdasar tabel 4 dapat dilihat bahwa nilai factor loading pada pattern matrix dan structured matrix merupakan nilai yang identik sebarannya. Hasil analisis dapat dilihat pada dimensi structured meals setting. Item mengelompok pada item 1, item 2 dan item 3 pada pattern matrix. Pengelompokan yang sama pada structured matrix sehingga dikatakan identik.

Hasil analisis pada structured meals timing dan dimensi family meals setting, nilai tertinggi berada pada kelompok item yang sama. Hal ini sesuai dengan pemilihan metode rotasi dan ekstraksi (Osborne dkk., 2014). Penamaan faktor/ dimensi tidak mengalami perubahan karena item mengelompok pada dimensi yang dihipotesakan. Seleksi item dilakukan dengan membatasi item yang memiliki factor loading lebih dari .4 yang dinyatakan valid. Nilai factor loading yang dicantumkan dalam matrix yaitu nilai $>.4$ sehingga nilai factor loading $<.4$ tidak dicantumkan hasil analisis. Konstrak skala lingkungan makan terstruktur terdiri atas dimensi structured meals setting, structured meals timing, family meals setting dengan factors loading bergerak antara .649 - .883. Nilai factor loading dapat dilihat pada tabel 8. Koefisien korelasi alpha cronbach menunjukkan angka lebih dari .7 (Mediocre) sehingga reliabilitas dapat diterima. Batas kriteria factors loading diterima .4 dengan $\mathrm{N}>300$ (Osborne dkk., 2014). Koefisien korelasi alpha cronbach dan AVE pada tiap dimensi dapat dilihat pada tabel 5 .

Tabel 5

Reliabilitas Skala Lingkungan Makan Terstruktur

\begin{tabular}{lc}
\hline \multicolumn{1}{c}{ Dimensi } & $\begin{array}{c}\text { Alpha } \\
\text { cronbach }\end{array}$ \\
\hline Structured meals setting & .739 \\
Structured meals timing & .785 \\
Family meal settting & .738 \\
\hline
\end{tabular}

Seleksi item menunjukkan lima item gugur (dimensi structured meals setting item 4 dan 5, dimensi structured meals timing item 4 dan 5, serta family meals setting item 1). Item tersebut dikeluarkan untuk analisis CFA sehingga skala lingkungan makan terstruktur hanya terdiri dari 10 item.

Hasil confirmatory factors analysis (CFA) dengan jumlah responden sebanyak 202 orang menunjukkan goodness of fit (GOF) model dapat diterima. Model skala lingkungan makan terstruktur dapat diterima setelah dimodifikasi. Nilai GOF menunjukkan chi square $\left(\chi^{2}\right)=2.468, p$ values $=.000$ (bad fit), comparative fit index (CFI = .944, good fit), goodness of fit index $(\mathrm{GFI}=.937$, good fit), root mean square residual (RMSEA $=.080$, good fit), normed fit index (NFI = .910, good fit) dan adjusted goodness of fit index (AGFI = .881 , moderate fit). Model skala lingkungan makan terstruktur yang terdiri atas tiga dimensi dan sepuluh item dapat diterima.

Tabel 6

Pemenuhan Kriteria Goodness of Fit oleh Model

\begin{tabular}{lccc}
\hline Kriteria & $\begin{array}{c}\text { Target tingkat } \\
\text { kecocokan }\end{array}$ & Hasil & $\begin{array}{c}\text { Kesim- } \\
\text { pulan }\end{array}$ \\
\hline$\left(x^{2}\right) p-$ & $\mathrm{P}>.05$ & 2.468, & Bad fit \\
value & $($ Good fit $)$ & $\mathrm{p}=.000$ & \\
CFI & $\geq .9($ Good fit $)$ & .944 & Good fit \\
& $.08 \leq$ CFI $<.9$ & & \\
& $($ Marginal fit $)$ & & \\
GFI & $\geq .9($ Good fit $)$ & .937 & Good fit \\
& $.08 \leq$ GFI .9 & & \\
& $($ Marginal fit $)$ & & \\
RMSEA & $\leq .08($ Good fit $)$ & .080 & Good fit \\
& $<.05($ Close fit $)$ & & \\
NFI & $\geq .9($ Good fit $)$ & .910 & Good fit \\
& $.08 \leq$ NFI $<.9$ & & \\
& $($ Marginal fit $)$ & & \\
AGFI & $\geq .9$ (Good fit $)$ & .881 & Margi- \\
& $.08 \leq$ AGFI $<.9$ & & nal fit \\
& $($ Marginal fit $)$ & & \\
\hline
\end{tabular}

Tabel 7

Korelasi antar Konstrak dan Akar Kuadrat AVE

\begin{tabular}{llll}
\hline & SMS & SMT & FMS \\
\hline SMS & .723 & & \\
SMT & .417 & .760 & \\
FMS & .431 & .519 & .699 \\
\hline Ket: & & \\
SMS: Structured meals setting & \\
SMT: Structured meals timing &
\end{tabular}




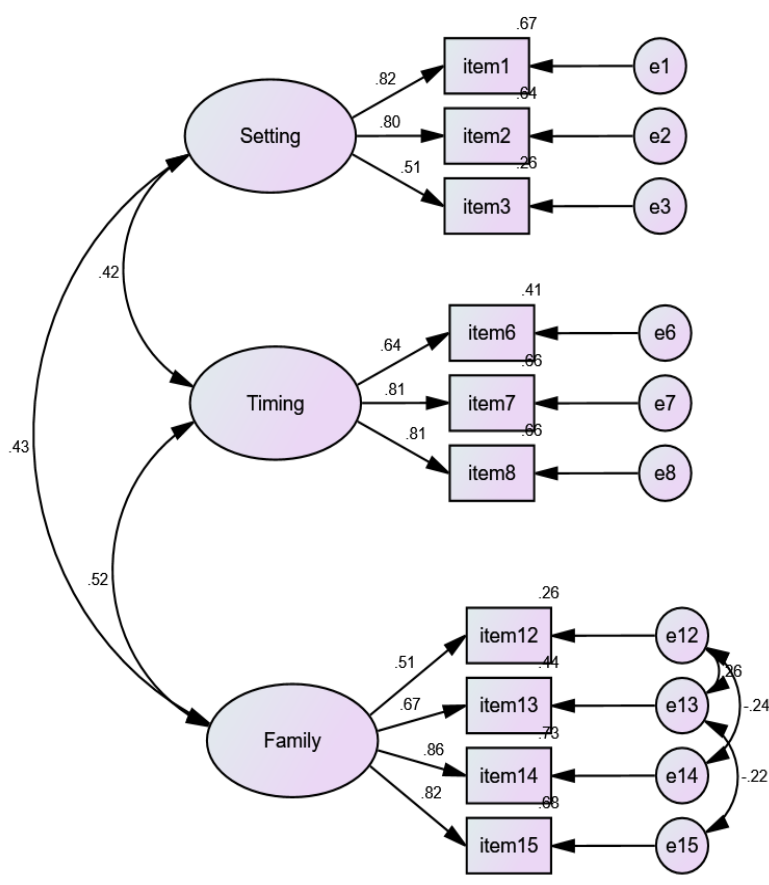

Gambar 2. Model CFA skala lingkungan makan terstruktur

Hasil analisis menunjukkan factor loading pada semua item $>.5$ sehingga semua item dinyatakan valid. Factors loading pada 10 item bergerak dari .503 .819. Data dapat dilihat pada tabel 8. Item mampu mengukur konstrak pada masingmasing dimensinya. Masing-masing dimensi mampu membedakan antara dimensi yang satu dengan dimensi yang lainnya. Validitas diskriminan dapat dilihat berdasar nilai average variance error (AVE). AVE dapat dihitung dengan rumus jumlah kuadrat factor loading dibagi jumlah item. AVE ketiga dimensi yaitu: structured meals setting sebesar .523, structured meals timing sebesar .577 dan family meals setting sebesar .482 . Construct reliability (CR) bergerak dari .760 - .802. Hasil ini telah memenuhi batas penerimaan. Validitas diskriminan skala lingkungan makan terstruktur disajikan pada tabel 7.

Pada tabel 7 tampak konstrak laten memiliki validitas diskriminan yang baik. Hal ini dapat dilihat pada nilai akar kuadrat
AVE masing-masing konstrak laten yang lebih tinggi nilainya dibanding dengan korelasi antara konstrak. Skala lingkungan makan terstruktur memiliki validitas diskriminan yang baik. Konstruk masingmasing dimensi mampu membedakan antara konstrak yang satu dengan lainnya.

Gambar 2 menampilkan hasil analisis model skala lingkungan makan terstruktur setelah dimodifikasi. Nilai factor loading dapat dilihat dari anak panah pada indikator. Dimensi family meals setting dilakukan constraint terhadap error pada itemnya. Constraint memungkinkan dapat dilakukan apabila konstrak masih mengukur hal yang sama. Langkah selanjutnya yaitu melakukan seleksi item. Item yang tidak memenuhi factor loading dikeluarkan. Pertimbangan yang dipakai dalam seleksi item yaitu item memenuhi batas kriteria factor loading $>.5$ dan item memiliki sumbangan yang signifikan dalam pengukuran konstrak lingkungan makan terstruktur. Hasil analisis exploratory factors analysis dan conformatory factors analysis item diseleksi secara bertahap. Adapun seleksi berdasar hasil analisis CFA tidak ada item yang direduksi. Semua item memenuhi kriteria $>.5$ sehingga semua item dinyatakan valid. Rangkuman sebaran item dan factor loading setelah melalui proses analisis EFA dan CFA dapat dilihat pada tabel 8.

Berdasarkan hasil analisis baik EFA maupun CFA dapat disimpulkan skala lingkungan makan terstruktur telah memenuhi kriteria psikometrik. Skala lingkungan makan terstruktur dapat digunakan sebagai alat ukur karena terbukti mampu mengukur konstrak dan cukup reliabel ketika diujicobakan pada subjek yang berbeda. Skala lingkungan makan terstruktur telah memenuhi uji validitas dan reliabilitas. Pengembangan alat ukur ini sejalan dengan konsep Jansen dkk. (2014). Ketiga dimensi dapat dipertahankan untuk mengukur konstrak skala lingkungan makan terstruktur yang sesuai dengan budaya masyarakat Makassar. 
Tabel 8

Seleksi Item Berdasar EFA dan CFA

\begin{tabular}{|c|c|c|}
\hline Dimensi & Item & $\begin{array}{l}\text { Factor } \\
\text { loading }\end{array}$ \\
\hline \multirow[t]{5}{*}{$\begin{array}{l}\text { Structured } \\
\text { meals } \\
\text { setting }\end{array}$} & $\begin{array}{l}\text { 1. Mengajarkan anak } \\
\text { supaya makan } \\
\text { dengan cara duduk } \\
\text { tenang dan sopan }\end{array}$ & .817 \\
\hline & $\begin{array}{l}\text { 2. Mengajarkan cara } \\
\text { makan yang benar } \\
\text { pada anak } \\
\text { (memegang sendok } \\
\text { dengan benar, duduk } \\
\text { yang baik, dan lain- } \\
\text { lain) }\end{array}$ & .803 \\
\hline & $\begin{array}{l}\text { 3. Saya mengharuskan } \\
\text { anak makan di meja } \\
\text { makan }\end{array}$ & .508 \\
\hline & $\begin{array}{l}\text { 4. Saya menemani anak } \\
\text { saat makan }\end{array}$ & $\begin{array}{l}\text { Gugur } \\
\text { (EFA) }\end{array}$ \\
\hline & $\begin{array}{l}\text { 5. Saya memangggil- } \\
\text { kan teman untuk } \\
\text { menemani anak } \\
\text { makan }\end{array}$ & $\begin{array}{l}\text { Gugur } \\
\text { (EFA) }\end{array}$ \\
\hline \multirow[t]{6}{*}{$\begin{array}{l}\text { Structured } \\
\text { meals timing }\end{array}$} & $\begin{array}{l}\text { 6. Saya memberi } \\
\text { makan anak } 3 \text { kali } \\
\text { sehari }\end{array}$ & .644 \\
\hline & $\begin{array}{l}\text { 7. Saya mengatur } \\
\text { jadwal pola makan } \\
\text { dengan ketat (pagi, } \\
\text { siang dan malam) }\end{array}$ & .812 \\
\hline & $\begin{array}{l}\text { 8. Jadwal makan anak } \\
\text { saya teratur }\end{array}$ & .812 \\
\hline & $\begin{array}{ll}\text { 9. Saya } & \text { tidak } \\
\text { membatasi } & \text { anak } \\
\text { minum susu } & \end{array}$ & $\begin{array}{l}\text { Gugur } \\
\text { (EFA) }\end{array}$ \\
\hline & $\begin{array}{l}\text { 10. Saya } \\
\text { mengharuskan anak } \\
\text { tidak makan }\end{array}$ & $\begin{array}{l}\text { Gugur } \\
\text { (EFA) }\end{array}$ \\
\hline & $\begin{array}{l}\text { camilan } \\
\text { mendekati } \\
\text { makan }\end{array}$ & \\
\hline \multirow[t]{5}{*}{$\begin{array}{l}\text { Family } \\
\text { meals } \\
\text { setting }\end{array}$} & $\begin{array}{lr}\text { 11. Saya } & \text { memasakkan } \\
\text { secara } & \text { terpisah } \\
\text { makanan } & \text { untuk } \\
\text { anak } & \end{array}$ & $\begin{array}{l}\text { Gugur } \\
\text { (EFA) }\end{array}$ \\
\hline & $\begin{array}{l}\text { 12. Anak makan } \\
\text { makanan yang sama } \\
\text { dengan keluarga }\end{array}$ & .507 \\
\hline & $\begin{array}{l}\text { 13. Anak mengikuti } \\
\text { aturan makan yang } \\
\text { berlaku di keluarga }\end{array}$ & .665 \\
\hline & $\begin{array}{l}\text { 14. Anak makan sesuai } \\
\text { dengan waktu } \\
\text { makan keluarga }\end{array}$ & .855 \\
\hline & $\begin{array}{l}\text { 15. Anak makan } \\
\text { bersama keluarga }\end{array}$ & .825 \\
\hline
\end{tabular}

Secara umum model skala lingkungan makan terstruktur yang terdiri dari tiga dimensi dinyatakan fit. Goodness of fit model dapat diterima: chi square $=2.468, \mathrm{p}$ $=.000$ (bad fit), CFI = .944 (good fit), GFI $=.937($ good fit $), \mathrm{RMSEA}=.080($ good fit $)$, $\mathrm{NFI}=.910($ good fit $)$ dan AGFI $=.881$ (moderate fit). Artinya model skala lingkungan makan terstruktur memenuhi batas kriteria uji model. Chi square tergolong bad fit. Hal ini disebabkan nilai chi square cenderung sensitif terhadap jumlah responden. Pada penelitian ini peneliti tidak membuang outlier (tidak mengubah mahalonobis) karena alasan terbatasnya responden penelitian. Beberapa kriteria GOF menunjukkan good fit, hanya AGFI yang moderat fit sehingga model dapat diterima.

Validitas diskriminan menunjukkan AVE bergerak dari .482 - .577 dengan construct reliability bergerak dari .760 .802. Nilai AVE kurang dari .5 masih dapat diterima apabila construct reliability > .6 (Hair dkk., 2014; Fornell \& Larcker, 1981, dalam Huang, 2013). Hal ini dimungkinkan terutama untuk instrumen yang baru disusun. Pada dimensi family meal setting AVE $<.5$ namun didukung construct reliabity $>.7$ sehingga masih memenuhi validitas.

Skala menjelaskan konstrak lingkungan makan terstruktur sebesar $63.987 \%$ dan selebihnya dijelaskan oleh konstrak lain. Sumbangan sebesar $63.987 \%$ telah memenuhi batas kriteria penerimaan yaitu > 45\%. Dimensi family meal setting memberikan sumbangan terbesar yaitu $38.349 \%$, diikuti dimensi structured meal setting sebesar $13.97 \%$ dan structured meals timing sebesar $11.662 \%$.

Dimensi family meal setting menunjukkan andil yang paling besar (38.349\%) dalam pengukuran konstrak (dibandingkan dimensi structured meals setting dan structured meals timing). Itemitem mampu mewakili konstraknya dengan baik. Ibu lebih termotivasi mengorganisir dan mengatur makan bersama keluarga. Ibu 
merasa kompeten dalam mengatur menu yang disajikan untuk keluarga dan menciptakan suasana kebersamaan pada saat makan. Hal ini sesuai dengan budaya di Makassar, anggota keluarga dianjurkan untuk bersama-sama makan pagi, makan siang, dan makan malam. Anggota keluarga diijinkan tidak hadir dalam acara makan bersama keluarga apabila ada urusan penting. Setiap anggota keluarga diharapkan mengusahakan hadir paling tidak pada saat makan malam (Ibnu dkk., 2013). Hal ini sejalan dengan Suggs dkk. (2018) makan di rumah bersama keluarga memiliki pengaruh positif terhadap konsumsi makanan pada anak.

Nilai-nilai religi menjadi pedoman dalam menentukan tatakrama makan. Masyarakat Makassar sebagian besar memeluk agama Islam sehingga aturan disesuaikan dengan Syariah Islam. Misalnya aturan makan tidak boleh berdiri. Hal ini disesuaikan dengan budaya makan bersama dengan duduk bersila atau melingkar di meja makan. Aturan ini pada masa sekarang sering diabaikan oleh sebagian ibu (Sohrah, 2016). Hal yang penting dilakukan ibu menegakkan aturan yang sudah berlaku. Hal ini relevan dengan item-item pada skala lingkungan makan terstruktur.

Validitas konvergen dapat dilihat pada structure matrix, pada tiap dimensi nilai factor loading tertinggi sesuai item. Hal ini menggambarkan item memiliki korelasi yang tinggi terhadap konstraknya. Validitas diskriminan dapat dilihat pada rendahnya korelasi item terhadap konstrak item yang lain (lihat tabel 7). Konsistensi internal menunjukkan alpha cronbach sebesar .785. Masing-masing dimensi menunjukkan alpha cronbach pada hasil EFA dan construct reliability pada hasil CFA > .7 sehingga ketiga dimensi memenuhi kriteria reliabilitas. validitas konstrak mampu mengukur konstrak lingkungan makan terstruktur dan cukup reliabel.

Hasil analisis EFA dan CFA menunjukkan skala lingkungan makan terstruktur terdiri atas 10 item. Hasil ini menunjukkan adanya kesamaan dan perbedaan konstrak dengan item yang disusun Jansen dkk. (2014). Konstrak pada ketiga dimensi menunjukkan kesamaan. Perbedaan terletak pada item 13, 15 dan 5, $9,10,11$. Item 13 dan 15 menjelaskan adanya norma dan budaya setempat. Item 5, 9, 10, dan 11 yang merupakan item yang memiliki kesamaan makna dengan Jansen dkk. (2014) tidak memenuhi factor loading sehingga dikeluarkan dari skala. Perbandingan item dapat dilihat pada tabel 9. Dimensi structured meals setting menunjukkan kesamaan pada setting anak duduk di meja makan. Sedangkan perbedaan terletak pada mengajarkan tata cara makan dan sopan santun sesuai norma yang berlaku pada masyarakat Makassar. Dimensi structured meal timing menunjukkan perbedaan makna dalam mengatur jadwal makan anak dibandingkan Jansen dkk. (2014). Dimensi family meal setting menunjukkan kesamaan makna pada item-itemnya yaitu anak makan menu yang sama dengan menu keluarga.

Item yang berbeda menunjukkan ada aturan atau norma dalam masyarakat. Makan bersama keluarga merupakan keharusan bagi masyarakat Makassar. Aturan waktu makan berbeda pada tiap negara, etnis, bahkan individu atau keluarga. Para ibu di Inggris mengatur waktu makan anak tidak lebih dari jam enam sore. Pada akhir pekan makan bersama keluarga, semua tinggal di meja makan sampai selesai makan (Carnell dkk., 2011). Anak usia prasekolah dari etnis Hispanic lebih cenderung makan bersama keluarga dan mengurangi makan di depan TV dibandingkan anak dari AfricanAmerican (Skala dkk., 2012). Kelebihan penelitian ini telah mengintegrasikan EFA dan CFA sehingga struktur faktor/ dimensi telah sesuai dengan budaya masyarakat setempat. Dimensi konstrak lingkungan makan terstruktur telah diverifikasi sehingga validitas dan reliabilitas telah memenuhi properti psikometrik. 
Tabel 9

Perbandingan Item

\begin{tabular}{|c|c|c|c|c|}
\hline $\begin{array}{c}\text { Dime } \\
\text { nsi }\end{array}$ & & Item penelitian & $\begin{array}{l}\text { Item (Jansen } \\
\text { dkk., 2014) }\end{array}$ & Ket. \\
\hline \multirow[t]{5}{*}{$S M S$} & 1. & $\begin{array}{l}\text { Mengajarkan anak } \\
\text { supaya makan } \\
\text { dengan cara duduk } \\
\text { tenang dan sopan }\end{array}$ & $\begin{array}{l}\text { Saya } \\
\text { membiarkan } \\
\text { anak makan } \\
\text { sambil berjalan- } \\
\text { jalan }\end{array}$ & Valid \\
\hline & 2. & $\begin{array}{l}\text { Mengajarkan cara } \\
\text { makan yang benar }\end{array}$ & $\begin{array}{l}\text { Anak saya } \\
\text { duduk ketika } \\
\text { makan }\end{array}$ & Valid \\
\hline & 3. & $\begin{array}{l}\text { Saya mengharus- } \\
\text { kan anak makan di } \\
\text { meja makan }\end{array}$ & $\begin{array}{l}\text { Saya menuntut } \\
\text { anak makan di } \\
\text { meja }\end{array}$ & Valid \\
\hline & 4. & $\begin{array}{l}\text { Saya menemani } \\
\text { anak saat makan }\end{array}$ & - & Gugur \\
\hline & 5. & $\begin{array}{l}\text { Saya memang- } \\
\text { gilkan teman } \\
\text { untuk menemani } \\
\text { anak makan }\end{array}$ & $\begin{array}{l}\text { Berapa kali } \\
\text { Anda } \\
\text { meneguhkan } \\
\text { tempat anak } \\
\text { harus makan? }\end{array}$ & Gugur \\
\hline \multirow[t]{5}{*}{$S M T$} & 6. & $\begin{array}{l}\text { Saya memberi } \\
\text { makan anak } 3 \mathrm{X} \\
\text { sehari }\end{array}$ & - & Valid \\
\hline & 7. & $\begin{array}{l}\text { Saya mengatur } \\
\text { jadwal pola makan } \\
\text { dengan ketat } \\
\text { (pagi, siang dan } \\
\text { malam) }\end{array}$ & $\begin{array}{l}\text { Saya membiar- } \\
\text { kan anak me- } \\
\text { mutuskan } \\
\text { sendiri kapan } \\
\text { anak makan } \\
\text { sesuai } \\
\text { keinginannya }\end{array}$ & Valid \\
\hline & 8. & $\begin{array}{l}\text { Jadwal makan } \\
\text { anak saya teratur }\end{array}$ & $\begin{array}{l}\text { Saya } \\
\text { memutuskan } \\
\text { waktu kapan } \\
\text { anak makan }\end{array}$ & Valid \\
\hline & 9. & $\begin{array}{l}\text { Saya tidak } \\
\text { membatasi anak } \\
\text { minum susu }\end{array}$ & - & Gugur \\
\hline & 10. & $\begin{array}{l}\text { Saya } \\
\text { mengharuskan } \\
\text { anak tidak makan } \\
\text { camilan saat } \\
\text { mendekati waktu } \\
\text { makan }\end{array}$ & $\begin{array}{l}\text { Saya } \\
\text { memutuskan } \\
\text { kapan waktu } \\
\text { makan snack }\end{array}$ & Gugur \\
\hline \multirow[t]{5}{*}{$F M S$} & 11. & $\begin{array}{l}\text { Saya memasakkan } \\
\text { secara terpisah } \\
\text { makanan untuk } \\
\text { anak }\end{array}$ & $\begin{array}{l}\text { Saya } \\
\text { memasakkan } \\
\text { terpisah untuk } \\
\text { anak }\end{array}$ & Gugur \\
\hline & 12. & $\begin{array}{l}\text { Anak makan } \\
\text { makanan yang } \\
\text { sama dengan } \\
\text { keluarga }\end{array}$ & $\begin{array}{l}\text { Anak saya } \\
\text { makan makanan } \\
\text { yang sama } \\
\text { dengan keluarga }\end{array}$ & Valid \\
\hline & 13. & $\begin{array}{l}\text { Anak mengikuti } \\
\text { aturan makan } \\
\text { yang berlaku di } \\
\text { keluarga }\end{array}$ & - & Valid \\
\hline & 14. & $\begin{array}{l}\text { Anak makan } \\
\text { sesuai dengan } \\
\text { waktu makan } \\
\text { keluarga }\end{array}$ & $\begin{array}{l}\text { Anak saya } \\
\text { makan menu } \\
\text { utama keluarga }\end{array}$ & Valid \\
\hline & 15. & $\begin{array}{l}\text { Anak makan } \\
\text { bersama keluarga }\end{array}$ & - & Valid \\
\hline
\end{tabular}

Keterbatasan penelitian ini yaitu jumlah responden yang masih terbatas hanya memenuhi jumlah standar minimal secara statistik untuk uji statistik EFA (Osborne dkk., 2014) dan CFA. Pengambilan data hanya dilakukan di kota Makassar sehingga belum representatif untuk digeneralisasi pada daerah atau budaya yang berbeda. Peneliti selanjutnya dapat melakukan uji coba pada etnis yang berbeda untuk lebih menyempurnakan alat ukur ini. Penelitian belum menguji secara empiris validity based on interpretative sehingga peneliti selanjutnya dapat mengujinya secara empirik.

Keterbatasan yang lain yaitu belum menggali secara spesifik lingkungan makan terstruktur terkait tujuan tertentu. Tema masih menggambarkan perilaku umum yang merupakan kebiasaan sehari-hari dalam mengatur dan mengorganisir lingkungan makan. Adanya temuan bahwa kendala waktu (time constraint) menjadi hambatan bagi ibu bekerja dan banyaknya kasus problem perilaku makan pada anak (Rifani dkk., 2015) dapat dikaji lebih lanjut, bagaimana ibu bekerja dengan kendala waktu mampu mengorganisir dan mengatur lingkungan makan anak.

Implikasi berdasarkan temuan ini yaitu skala lingkungan makan terstruktur telah memenuhi uji validitas konstrak berdasar validitas isi dan validitas struktur internal. Skala lingkungan makan terstruktur telah memenuhi kriteria psikometrik sehingga dapat diaplikasikan di lapangan.

\section{Simpulan}

Skala lingkungan makan terstruktur terdiri dari tiga dimensi dan diuraikan menjadi 10 item yaitu structured meals setting, structured meals timing, dan family meal setting. Skala telah melalui proses adaptasi sesuai dengan latar belakang budaya masyarakat Makassar, khususnya pada ibu yang memiliki anak usia dini. Proses validasi konstrak berdasar validitas 
isi telah memenuhi uji I-CVI dan S-CVI. Proses validitas berbasis struktur internal telah memenuhi uji analisis faktor eksploratori dan analisis faktor konfirmatori. Validitas konvergen dan validitas diskriminan cukup baik. Skala lingkungan makan terstruktur dapat digunakan sebagai alat ukur yang valid dan reliabel.

\section{Daftar Pustaka}

Adriani, M., \& Wirjatmadi, B. (2014). Pengantar gizi masyarakat. Kencana Prenada Media Group.

Aidid, M. K., Sulaiman, \& Side, S. (2017). Pengaruh pemberian pola makanan sehat terhadap status gizi anak-anak didik TK bunga asya. Jurnal Scientific Phinisi, 3, 17-26.

Bornstein, M. H. (2002). Handbook of parenting being and becoming a Parent, Volume 3 (Second Edition). Lawren Elbraun Associates Publisher.

Bornstein, M. H. (2002). Handbook of parenting biology and ecology parenting, Volume 2 (Second Edition). Lawren Elbraun Associates Publisher.

Carnell, S., Cooke, L., Cheng, R., Robbins, A., \& Wardle, J. (2011). Parental feeding behaviours and motivations: A qualitative study in mothers of UK preschoolers. Appetite 57, 665-673. https://doi.org/10.1016/j.appet.2011.08.0 09

Casey, C. M., Cook-Cottone, C., \& BeckJoslyn, M. (2012). An overview of problemantic eating and food-related behavior among foster children: Definition, etiology, intervention. Child and Adolescent Social Work Journal, 29, 307-322.

Daniels, L. A. (2019). Feeding practices and parenting: a pathway to child health and family happiness. Annalsof Nutrition \& Metabolism, 74(suppl 2), 29-42. https://doi.org/10.1159/000499145

Fiamanatillah, R. F., Ningtyias, W. F., \& Rohmawati, N. (2019). Kontribusi zat gizi makan siang sekolah dan kecukupan gizi terhadap status gizi siswa di SD al- furqan Jember. Buletin Penelian Sistem

Kesehatan, 22(4), 265-271.

https://doi.org/10.22435/hsr.v22i4.1297

Finnane, J., Jansen, E., Mallan, K. M., \& Daniels, L. A. (2017). Mealtime structure and responsive feeding practices are associated with lessfood fussiness and more enjoyment of food in children. Journal of Nutrition Education and Behavior, 49(1), 11-18. https://doi.org/10.1016/j.jneb.2016.08.00 7

Grolnick, W. S. (2009). The role of parents in facilitating autonomous self-regulation for education. Theory and Research in Education, 7(2), 164-173.

Grolnick, W. S., Jacquelyn, N., RafteryHelmer, Kristine, N., Marbel., Elisabeth, S., Flamm, Esteban, V., Cardemill, \& Sanchez, M. (2014). Parental provision of structure: Implementation and correlates in three domains. MerrilPalmer Quarterly, 60(3), 355-384. https://doi.org/10.1353/mpq.2014.0016

Hair, J. F., Black, W. C., Babin, B., \& Anderson, R. E. (2014). Multivariate data analysis (Seventh edition). PearsonEducation Limited.

Holden, G. W. (2014). Parenting a dynamic perspective. SAGE Publication AsiaPasific. Ltd.

Hu, Z., \& Li, J. (2015). The integrating of EFA and CFA: One method of evaluating the construct validity. Global Journal of Human-Social Science: An Arts \& Humanities-Psychology 15(6).

Huang, C., Wang, Y., Wu, T., \& Wang, P. (2013). An empirical analysis of the antecedents and performance consequences of using the moodle platform. International Journal of Information and Education Technology, 3(2), 217-221.

Ibnu, I. N., Thaha, A. R. M., \& Jafar, N. (2013). Pola asuh pemberian makanan pendamping ASI (MP-ASI) pada ibu baduta di Tanah Kajang Ammatoa kabupaten Bulukumba. Media Kesehatan Masyarakat Indonesia. The Indonesian Journal of Public Health, 9(4), 257-263. 
Jansen, E., Mallon, K. M., Nicholson, J. M., \& Daniles, L. A. (2014). The feeding practices and structure questionnaire: Construction and initial validation in sampel of Australian fisrt-time mothers and their 2-year olds. International Joaurnal of Behavior Nutrition and Physical Activity, 11(72). https://doi.org/10.1186/1479-5868-11-72

Kompasiana (2015, Desember 18). Budaya Makan Lokal dan Perbaikan Gizi. Kompasiana.com. https://www.kompasiana.com/arundhana _s.gz/5519c3718133110a7b9de0c1/buda ya-makan-lokal-dan-perbaikan-gizi

Melbye, E. L. Ǿgaard, T., Ǿverby, N. C., \& Hansen, H. (2013). Parental food related behaviors and family meal frequencies: Associations in Norwegian dyads of parents and preadolescent children. BioMed Central Public Health, $13,820-829$.

Morin, P., Demers, K., Turcotte, S., \& Mongeau, L. (2013). Association between perceived self-efficacy related to meal mangement and food coping strategies among woriking parents with preschool children. Appetite, 65, 43-50.

Murashima, M., Hoerr, S. L., Hughes, S. O., \& Kaplowitz, S. (2011). Confirmatory factor analysis of a questionnaire measuring control in parental feeding practices in mothers of head start children. Appetie, 56. 594-601. https://doi.org/10.1016/j.appet.2011.01.0 31

Ogden, J. (2014). The good parenting food guide: Managing what children eat without making food a problem. John Wiley \& Sons, Ltd.

Osborne, J. W., Costello, A. B., \& Kellow, J. T. (2014). Best practices in exploratory factor analysis (pp. 86-99). CreateSpace Independent Publishing Platform.

Rifani, R., Suryanto, \& Suminar, D. R. (2015). Social-demographic factors on maternal feeding on working mothers with 4-6 years old child. Prosiding. ICP HESOS. https:// dx.doi.org/10.2991/icamr-18.2019.134
Sohrah (2016). Etika makan dan minum dalam pandangan syariah. Al-Daulah : Jurnal Hukum Pidana dan Ketatanegaraan, 5(1), 21-41. https://doi.org/10.24252/ad.v5i1.1439

Skala, K., Chuang., R., Evans, A., Hedberg, A., Dave, J., \& Sharma, S. (2012). Ethnic differences in the home food environment and parental food pracices among familes of low-income hispanic and african-american preschoolers. Journal of Immigrant Minority Health, 14(6), 1014-1022. https://doi.org/10.1007/s10903-0129575-9

Snuggs, S., Houston_Price, C., \& Harvey, K. (2019). Development of a parental feeding goal measure: The family mealtime goals questionnaire. Frontiers in Psychology, 10, 455. https://doi.org/10.3389/fpsyg.2019.0045 5

Suggs, L. S., Bella, S. D., Rengelov, N., \& Marques-Vidal, P. (2018). Is it better at home with my family? The effects of people and place on children's eating behavior. Appetite, 121, 111-118. https://doi.org/10.1016/j.appet.2017.11.0 02

World Health Organization. (2017). Global database on child growth and malnutrition, Joint child malnutrition estimates-levels and trends (2017 edition). World Health Organization. https://www.who.int/nutgrowthdb/estima tes2016/en/

Yussof, M. S. B. (2019). ABC of content validation and content validity index culculation. Education in Medicine Journal, $\quad 11(2), \quad 49-54$. https://doi.org/10.21315/eimj2019.11.2.6 